\title{
撫順式頁岩乾溜法の解析と改善 (II)
}

一一眧和30年 3 月 20 日受理——

\section{出光興産怢式会社 北脇 金 治}

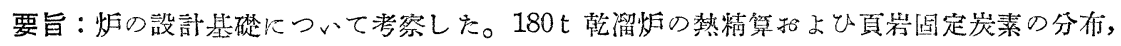

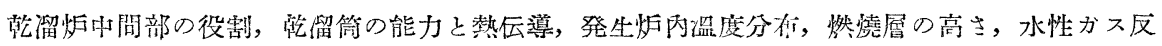
応速度尔とについて解析し設計の基礎を明らかにした。尔扎とれらの解析によつて次のことき 費項か明らかとなつた。

1. Haslam らの实験結果から導いた簡单化した式によつて訂算したがス組成が灾際とよく一 致する。

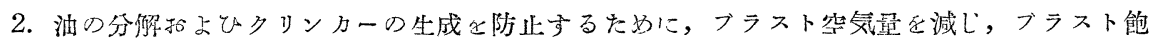

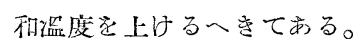

3 発生炬內にて頁岩圆定炭素つ的 $\frac{1}{2}$ がス化されている。残りの固定炭素众有勃に优用す れば热ガスの供給は不要となる。

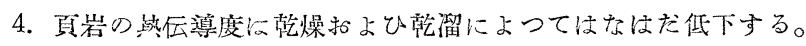

5. 発生炉丽水性分ス反応速度注略一次反它として訣算することかてきる。

\section{I 緒 言}

$180 \mathrm{t}$ 乾溜炉の設棓基礎（熱精算, 蓺伝導, 反応速 度なとについて考察する。

\section{II 設計基礎に関する考察}

\section{1 熱 精 算}

頁岩装入量は $200 \mathrm{t} /$ 日，発生ガスの成分は平均して $\mathrm{CO}_{2} 22.0 \%, \mathrm{CO} 3.9 \%, \mathrm{H}_{2} 13.4 \%, \mathrm{CH}_{4} 6.7 \%$ あ゙あ る。発生ガス量は頁岩 $\mathrm{kg}$ 当り $0.274 \mathrm{~m}^{3}$ であつて, 乾溜ガス量 $0.042 \mathrm{~m}^{3}$ そ引けば，発生炉ガス量は 0.232 $\mathrm{m}^{3}$ となる。この発生ガスの組成と第 4 表乾溜ガスの

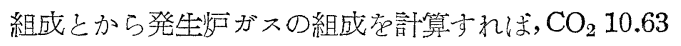
$\%, \mathrm{CO} 42 \%, \mathrm{H}_{2} 9.73 \%, \mathrm{CH}_{4} 2.82 \%, \mathrm{~N}_{2} 6362 \%$ となる。この中の $\mathrm{CH}_{4} 2.82 \%$ は大粒の頁岩の中心部 に残つた油分が発生炉内て溜出し熱分解を受けたもの と考元られる。 $\mathrm{CH}_{4}$ 峜除外寸れは発生炉ガスの量は $0.225 \mathrm{~m}^{3}$ ，その中の $\mathrm{H}_{2}$ は $10 \%$ すなわち $0.0225 \mathrm{~m}^{3}=$ $0.001 \mathrm{~kg}-\mathrm{mol}$ となる。

$\mathrm{H}_{2} 0.001 \mathrm{~kg}-\mathrm{mol}$ は水蒸気の分解量に等しく,式 (5) によつて計算すれは同時に CO $0.000432 \mathrm{~kg}-\mathrm{mol}, \mathrm{CO}_{2}$ $0.000283 \mathrm{~kg}-\mathrm{mol}$ 觉生成する。ブラス下空気 $0.185 \mathrm{~m}^{3}$ の燃焼による $\mathrm{CO}_{2} 0.001735 \mathrm{~kg}-\mathrm{mol}, \mathrm{N}_{2} 0.006525 \mathrm{~kg}$ mol と合計すれば，発生炬ガス量は $0.009975 \mathrm{~kg}-\mathrm{mol}$ $=0.223 \mathrm{~m}^{3}$, これに $\mathrm{CH}_{4}$ の量 $2.82 \%$ を加えれは 0.23 $\mathrm{m}^{3}$ となり，実際の発生炉がス量 $0.232 \mathrm{~m}^{3}$ とよく一致 する。すなわち式（5）による関孫はほとんと完全に 成立している。水蒸気の量はブラスト中に $0.242 \mathrm{~kg}$, 灰血からの蒸発 $0.11 \mathrm{~kg}$, 計 $0.352 \mathrm{~kg}=0.01954 \mathrm{~kg}-\mathrm{mol}$ でありこのうち $0001 \mathrm{~kg}-\mathrm{mol}$ だけ分解なるから， 分解率は $5.12 \%$ ，残りは $0.01854 \mathrm{~kg}-\mathrm{mol}=0334 \mathrm{~kg}$ と なる。

頁岩中の固定炭素の分布々みる。ます乾溜により水 分 7.9\%，酒分 5.97\%，ガス 3.92\% (計算值) 在失 い, 乾溜残渣の量は $82.21 \%$ となる。発生炉に打ける 固定孷素の消費量は然焼用に0 $0.001735 \mathrm{~kg}-\mathrm{mol}$ ，水蒸 気分解用に0.000717 $\mathrm{kg}-\mathrm{mol}$ (式5による), 計 0.002452 $\mathrm{kg}-\mathrm{mol}=0.0294 \mathrm{~kg}$ ，与なわち頁岩の $2.94 \%$ ，したが つて頁岩灰量は $79.2 \%$ となる。頁岩の真の灰分は約 75\%であり, 従来の頁岩灰の分析からみて灰中の炭素 合有量は1〜1.5\%まて下げうるから,上の頁岩灰 79.27 \%の中にはまだ利用できる㞸素分が $3 \%$ 以上含まれて いる。一方熱がスによつて供給する熱量は水蒸気の替 樊妾除けは $70 \mathrm{kcal}$ 程度のものであり，それはわすか に0.89\%の炭素の然焼熱に等しい。

$180 t$ 炉の熱精算は第 16 表および第 9 区のことくで ある。

この熱精算の資料をとつた日の外気温度は零下 14 ${ }^{\circ} \mathrm{C}$ であつたから，頁岩疮 $0^{\circ} \mathrm{C}$ まで予熱するに必要な 熱量 $9.9 \mathrm{kcal}$ も加算されている。頁岩, 孷素抢よひガ 


\section{第16表 $180 \mathrm{t}$ 炉 熱 精 算 (頁岩 $\mathbf{k g}$ 当り)}

ブラスト空気 $0.185 \mathrm{~m}^{3}, 87^{\circ} \mathrm{C}, 5.5 \mathrm{kcal}$, 水蒸気 $0.242 \mathrm{~kg}, 151,7 \mathrm{kcal}$ 計 $157.2 \mathrm{kcal} \quad \cdots \cdots \cdots \cdots \cdot(+)$

碑㞸灰 $0.7927 \mathrm{~kg}, 75^{\circ} \mathrm{C}, 11.9 \mathrm{kcal}$, 水分 $12 \%, 7.1 \mathrm{kcal}$ 計 $19 \mathrm{kcal} \quad \cdots \cdots \cdots \cdots(-)$

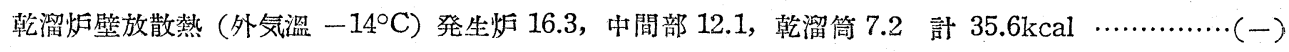

燃燒熱，空気 $0.185 \mathrm{~m}^{3}, \mathrm{CO}_{2} 0.001735 \mathrm{~kg}-\mathrm{mol} \times 94,300 \mathrm{kcal} 163.3 \mathrm{kcal} \quad \cdots \cdots \cdots \cdot \cdots(+)$

水蒸気分解 $0.001 \mathrm{~kg}-\mathrm{mol} \times 35,975 \mathrm{kcal}, 36 \mathrm{kcal}$

愁ガス $0.294 \mathrm{~m}^{3}, 580^{\circ} \mathrm{C}, 60.3 \mathrm{kcal}$, 水蒸気 $0.0262 \mathrm{~kg}, 22.6 \mathrm{kcal}$ 計 $82.9 \mathrm{kcal}$

油の乾溜分解など $15 \mathrm{kcal}$

頁岩の予熱， $-14^{\circ} \mathrm{C}, 3.6 \mathrm{kcal}$ ，水分 $0.079 \mathrm{~kg}$ ，熔融 $6.3 \mathrm{kcal}$ ，計 $9.9 \mathrm{kcal}$

出口ガス $0.567 \mathrm{~m}^{3}, 85^{\circ} \mathrm{C}, 15 \mathrm{kcal}$, 水蒸気 $0.439 \mathrm{~kg}, 274 \mathrm{kcal}$ 計 $289 \mathrm{kcal}$

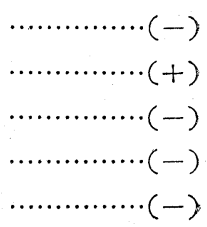

第 9 図 180 t炉 熱精 算 $[\mathrm{kcal} / \mathrm{kg}$ 頁岩]

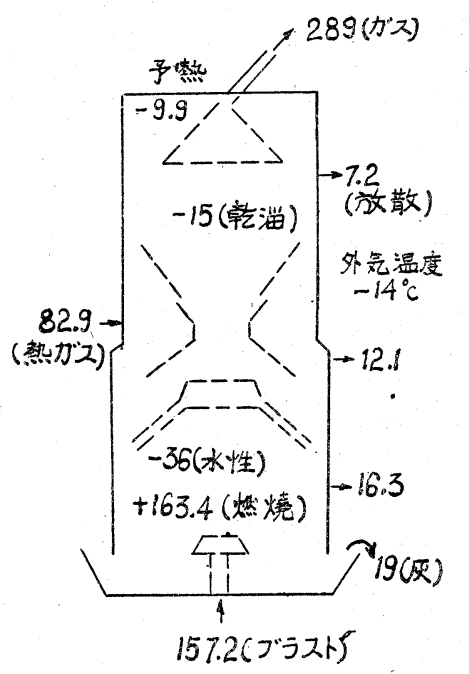

スの発熱量を加算すれば，それらの数值が大きいため に重点が不眀瞭になる恐れがあるので，精算表には載 せない方法をとつた。第16表において入熱量 $403.5 \mathrm{kcal}$, 出熱量 $401.3 \mathrm{kcal}$ で両者はよく一致している。

すでに説明したごとく，熱ガスを供給しながら一方 に抢いては多量の有効炭素を灰中に廃寨する結果とな つている。溜出油を分解させない方法を講じて，ブラ ス下空気量を増加し，固定炭素を有效に使用すれば， 熱倠スの供給を廃止することができるはずである。

\section{2. 中間部の機能}

乾溜筒と発生炉との間にある中間部における頁岩お よでガスの温度は第10図に示めすごとくである。

頁岩の温度を正確に知ることは困難であるが，ブラ ストを止めて測った時の温度をとることとする。頁岩 の温度は乾溜筒の下部に持い: $350^{\circ} \mathrm{C}$, 発生灯頂に拉 いて $530^{\circ} \mathrm{C}$, 分 $ᄌ$ の温度は発生师頂 $636^{\circ} \mathrm{C}$, 混合室内 $550^{\circ} \mathrm{C}$ である。

頁岩から油の溜出する温度は 360〜520 C(第 2 図)

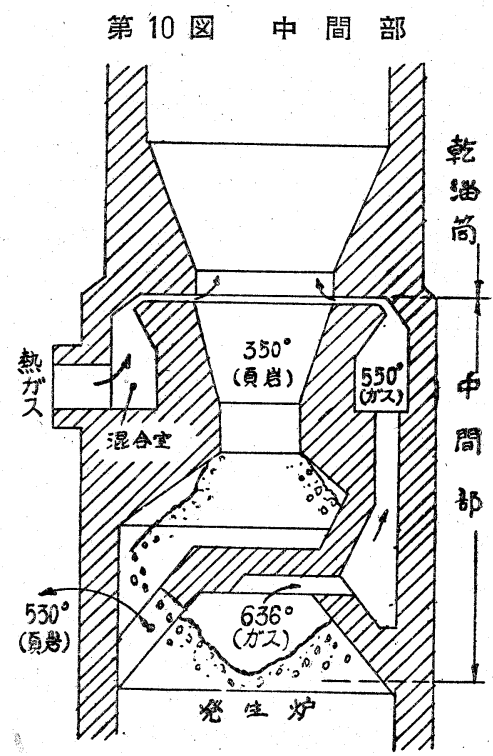

であるから，油の溜出は中閒部で行われていることが わかる。中間部の頁岩によつて占められる容積は 8.88 $\mathrm{m}^{3}$ であり, 頁岩の滞留時間は約 1 時間である。粗油 の収率がよい, 才なわち分解の少いのは, 発生炉梁ス の温度が従来よりも低いことしかもその永スの大部分 は煤瓦アーテの下部から煉瓦に囲まれた通路を経て混 合室に行くので, 高温のガスが油の蒸気に触れないこ とによるものと考えられる。頁岩の分解乾溜に就して 中間部が理想に近い役割を果していることがわかる。 煉瓦アーテが溜出油の分解防止にはなはだ役立つてい ることも明らかである。

3. 乾溜筒の能力

$180 \mathrm{t}$ 炉について 綜括伝熱倸数を求めてみる。ガス の温度は大口 $50^{\circ} \mathrm{C}$, 出口 $85^{\circ} \mathrm{C}$, 対数平均温度 $249^{\circ} \mathrm{C}$, 頁岩の温度は大口 $-14^{\circ} \mathrm{C}$, 出口 $350^{\circ} \mathrm{C}$, ガスと頁岩と の対数平均温度差 $144^{\circ} \mathrm{C}$, 乾溜に要する熱量は頁岩 1 $\mathrm{kg}$ 它 $0^{\circ} \mathrm{C}$ まで加温するに $9.9 \mathrm{kcal}$, 水分の蒸発に 49.4 kcal, 頁岩の加熱（水分のみを除き）に83.8kcal，合 
計 $143.1 \mathrm{kcal}$ ，頁岩装大量 $200 \mathrm{t} /$ 日，したがつて乾溜用 等量は $1.19 \times 10^{6} \mathrm{kcal} / \mathrm{hr}$ ，あるいは $64,800 \mathrm{kcal} / \mathrm{m}^{3} \cdot \mathrm{hr}$. 容積伝蓺係数 $h^{\prime}=450 \mathrm{kcal} / \mathrm{m}^{3} \cdot \mathrm{hr} .{ }^{\circ} \mathrm{C}$ となる。この $h^{\prime}$ の值は一般の乾燥充填塔の計算值に比べてはなはだ小 さい值である。

頁岩表面のガスの境膜係数を求めてみる。訫算は固 定層および流動層の熱移動を単一の式で現わした白井 隆氏(11)の式による。

$$
N_{u} \cdot \varepsilon=2.0+0.75 \cdot \operatorname{Rep}^{\mathrm{I} / 2} \cdot P_{7}{ }^{1 / 3} \cdot
$$

式中 $N_{u}$ はヌッセル下数 $\left(h D / k_{F}\right), \varepsilon$ は空間率は，

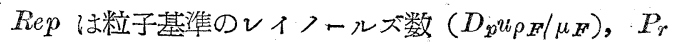
はプラントル数 $\left(O_{p} \mu_{F} / k_{F}\right)$ である。

頁岩粒の大きさについては，乾溜のもつとも困難な $50 \sim 40 \mathrm{~mm}$ 平均 $4.5 \mathrm{~cm}$ のもの祀考元る。1 $80 \mathrm{t}$ 炉の前 記の状態においてガス量は $4.61 \mathrm{~m}^{3} / \mathrm{sec}$, 空間速度 0.723 $\mathrm{m} / \mathrm{sec}$ ，通過時閒 $2 \mathrm{sec}$, ガスの比重 $0.534 \mathrm{~kg} / \mathrm{m}^{3}$, ガス の粘度 $0.232 \times 10^{4} \mathrm{~kg} / \mathrm{m} . \mathrm{sec}$, ガスの比熱 $0.336 \mathrm{kcal} / \mathrm{kg}$ ${ }^{\circ} \mathrm{C}$, ガスの熱伝導度 $0.0342 \mathrm{kcal} / \mathrm{m}, \mathrm{hr} .{ }^{\circ} \mathrm{C}$ である。こ れらの值を用い，式 (9)によつて訫算すれは $R e p=$ 748, $P_{r}=0.821, N_{u}=42.1$ ( $\varepsilon=0.5$ として), $h=32$ $\mathrm{kcal} / \mathrm{m}^{2} \cdot \mathrm{hr} .{ }^{\circ} \mathrm{C}$ をうる。乾溜筒の中に大きさ $4.5 \mathrm{~cm}$ の

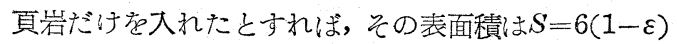
$/\left(\phi D_{p}{ }^{\circ}\right)=111 \mathrm{~m}^{2} / \mathrm{m}^{3}$ となり, 容積伝熱係数 $h^{\prime}=3,550$ $\mathrm{kcal} / \mathrm{m}^{3} \cdot \mathrm{hr} .{ }^{\circ} \mathrm{C}$ となる。

頁岩内部の伝熱をしらべる。頁岩の表面の温度が刻 々に変化するので，Gurney-Lurie らの式が使えない から，Schmidt の提出した非定常伝熱の作四法(15)を 用いて無限拡りの板状の頁岩を両面から加熱する場合 を考光てみる。頁岩の大きさは上と同様に $4.5 \mathrm{~cm}$ の のをとり，表面から中心までの距離 $2.5 \mathrm{~cm}$ を 4 等分し $\tau \Delta x$ とする。 $\Delta x$ と時間との関係は $\Delta \theta=(\Delta x)^{2} /(2 a)$ で 表わされる， $a$ は熱拡散率で $a=k /\left(O_{p} \rho\right)$ である. 頁岩 の熱伝導度 $k$ はコロラド産に対する值として $k=1.367$ $\mathrm{kcal} / \mathrm{m} . \mathrm{hr} .{ }^{\circ} \mathrm{C}$ が報告(1)されている。この值は砂岩の熱 伝導度に近い。頁岩の比熱は $0.23 \mathrm{kcal} / \mathrm{kg}^{\circ} \mathrm{C}$ であるが， ここでは頁岩中の水分 $7.9 \%$ の蒸発に必要な熱量 50.6 $\mathrm{kcal} / \mathrm{kg}$ を加算して $O_{p}=0.3745 \mathrm{kcal} / \mathrm{kg}^{\circ} \mathrm{C}$ とする。頁 岩の密度は $\rho=2.100 \mathrm{~kg} / \mathrm{m}^{3}$ である。これらの值によつ 乙熱拡散率 $a=0.001735 \mathrm{~m}^{2} / \mathrm{hr}, \Delta \theta=0.00914 \mathrm{hr}$ 苍う る。また頁岩が乾溜筒に滞留する時間は $2.32 \mathrm{hr}$ であ り，この間にガスの温度は $85^{\circ} \mathrm{C}$ から $550^{\circ} \mathrm{C}$ まで変化

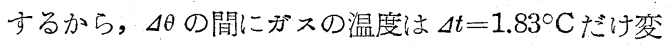
化する。

ガスと頁岩表面との間の境膜俰数はすでに計算した ごとく $32 \mathrm{kcal} / \mathrm{m}^{2} . \mathrm{hr} .{ }^{\circ} \mathrm{C}, \quad カ ゙ ス の$ 熱伝導度は 0.0342 $\mathrm{kcal} / \mathrm{m}^{2} . \mathrm{hr} .{ }^{\circ} \mathrm{C}$ であるから, 境膜の厚さは $0.001 \mathrm{~m}$ し かない。この境膜の厚さ虑作困に入れても影響は小さ いから省略し，汾温度と頁岩表面温度が等しいもの として，頁岩内部の温度上昇をみることとする，以上 の條件によつて作図したのが第11図である。

\section{第11図 真岩內溫度分布}

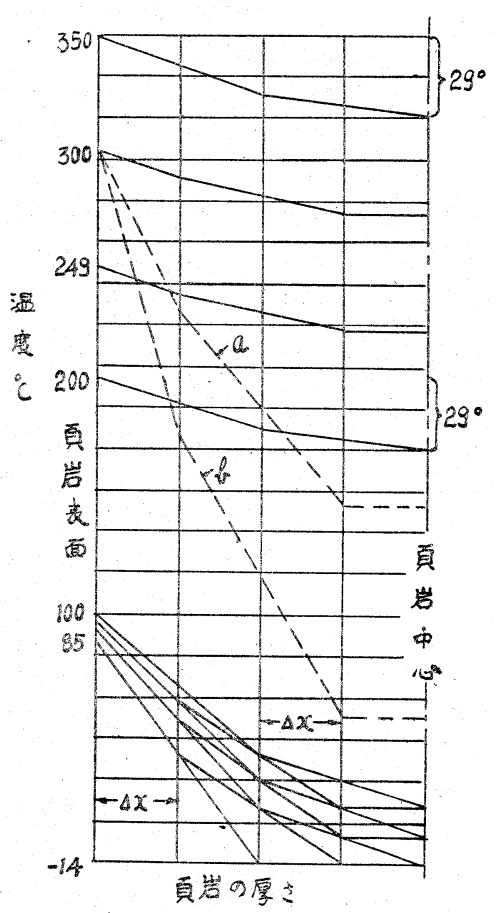

第11四をみるに，頁岩内の温度上昇は速く，表面温 度 $200^{\circ} \mathrm{C}$ 以上では表面と中心との温度差はわずかに $29^{\circ} \mathrm{C}$ となりほほ一定である。よつて 表面の単位面積 を流れる熱量は $g=3,540 \mathrm{kcal} / \mathrm{m}^{2} . \mathrm{hr}$ となり,仮りに綜 括俰数を計算すれば, $U=21.7 \mathrm{kcal} / \mathrm{m}^{2} \cdot \mathrm{hr} .{ }^{\circ} \mathrm{C}$, 容積伝 蓺保数は $h^{\prime}=2,410 \mathrm{kcal} / \mathrm{m}^{3} \cdot \mathrm{hr} .{ }^{\circ} \mathrm{C}$ となる。実際值 $h^{\prime}=$ $450 \mathrm{kcal} / \mathrm{m}^{3} \mathrm{hr} .{ }^{\circ} \mathrm{C}$ に比べてまだ大きな值である。しか も頁岩の大粒のみを対照とし，まだ頁岩を無限拡りの 板状として取り扱つているので, 実際の頁岩粒に対す る計算値はもつと大きいはずである。温度差もガスの 温度と頁岩の中心温度との美をとるべきである。

乾溜筒における実際の $h^{\prime}$ が小さい理由としては, 乾 溜筒内の温度 $288^{\circ} \mathrm{C}$ 以下の部分が精溜塔のごとき状態 にあること, 油膜の熱伝導度が小さいこと，乾溜筒出 ロガス温度が露点に近いから温度の測定を誤りやすい こと, 頁岩内部から逐次水分, 油分抢よで炭素分が失 われるにしたがって頁岩内部はきわめて多孔質とな り，頁岩の熱伝導度がはなはだ小さい值に変化してい 


\section{ることなどが考えられる。}

第 5 表によれば50t炬および $100 t$ 炬においては出 口のガス温度はそれぞれ $150^{\circ} \mathrm{C}$ 打よび $110^{\circ} \mathrm{C}$, 大口ガ ス温度はいずれも $600^{\circ} \mathrm{C}$ あいはそれ以上であつて， 乾溜筒を出る頁岩の温度も $550^{\circ} \mathrm{C}$ あるいはとれ以上 である。試みに容積伝熱係数(この場合は油母の分解 乾溜熱量も含む）を計算すればとれぞれ $h^{\prime}=320$ およ び $84 \mathrm{kcal} / \mathrm{m}^{3} . \mathrm{hr} .{ }^{\circ} \mathrm{C}$ となる。180t炬に㧅ててはすでに

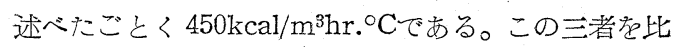
較するにガス抢よび頁岩の温度が高い、活に゙ $h^{\prime} か ゙$ 小さ くなつており，頁岩の多孔質による影響がもつとも大 きいものと考元られる。

乾燥した河砂（密度 $1,520 \mathrm{~kg} / \mathrm{m}^{3}, 20^{\circ} \mathrm{C}$ )に対しては $k=0.28 \mathrm{kcalm} . \mathrm{hr} .{ }^{\circ} \mathrm{C}$ のごとき值も載つている。しかし この值を用いて概算しても $h^{\prime}$ の值はなお害際よりも大 きい值となる。第11図にしめした点線 $a$ は $k=0.28 \mathrm{kcal}$ $/ \mathrm{m} . \mathrm{hr} .{ }^{\circ} \mathrm{C}$ とした場合, 点線 $b$ は $k=0.1 \mathrm{kcal} / \mathrm{m} . \mathrm{hr} .{ }^{\circ} \mathrm{C}$ とした場合の温度分布の一線究しめしたものである。 頁岩の熱伝導度は多分この両者の間にあるものと想像 される。な打進んで究明るすには頁岩の乾溜程度と測 定時の温度とを交えて, 頁岩の熱伝導度を実測する必 要加あると教光られる。熱伝導が小さくなるにしたが つて頁岩内の温度傾斜が大きくなるから, 炉内におけ る頁岩の温度測定もこの点を充分考慮して行わなけれ は⿺ならない。

\section{4. 発生炉内の状況}

発生炉内の温度抢よび各層 (予熱, 燃焼, 水性无 反応）の高さを調へてみる。発生炉内最高温度は約 1,000ㄷ゙ある。ブラス下は $87^{\circ} \mathrm{C}$ でり， $400^{\circ} \mathrm{C} に$ 予 熱され，燃焼して $1,095^{\circ} \mathrm{C}$ (理論的) となる(第 3 図). 灰血の水封に大る頁岩灰の温度は, 灰の持ち去る熱量 $19 \mathrm{kcal}$, 水の蒸発に $70.4 \mathrm{kcal}$, 計 $89.4 \mathrm{kcal}$ 老供給方る ものとして $490^{\circ} \mathrm{C}$ となる。これらの温度を四示すれば 第12罒のごとくである。

ブラスト予熱置の高され求める。ブラス下と井血か ら蒸発した水蒸気と寺 $400^{\circ} \mathrm{C}$ まで予熱するに要する

\section{第12図 登生炉內溫度}

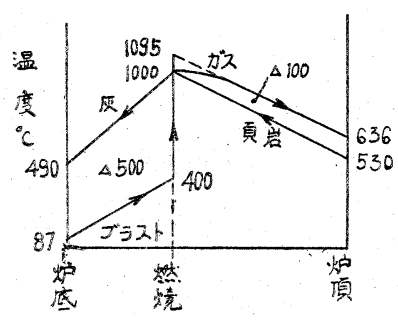

熱量は $580,000 \mathrm{kcal} / \mathrm{hr}$ ，頁岩の乾溜残渣学 $530^{\circ} \mathrm{C}$ から $1,000^{\circ} \mathrm{C}$ まで加熱するに要する熱量は $856,000 \mathrm{kcal} / \mathrm{hr}$ である。頁岩とガスとの対数平均温度美は $500^{\circ} \mathrm{C}$ 打よ び $100^{\circ} \mathrm{C}$ となり, 発生炉の容積は $24.7 \mathrm{~m}^{3}$ であるから， 発生炉内の上部之下部に抢沙容積伝熱䋆数ね同值と 仮定するならば，ブラス下予熱層の容積は $2.95 \mathrm{~m}^{3}$,

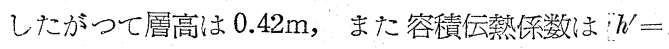
$393 \mathrm{kcal} / \mathrm{m}^{3} \cdot \mathrm{hr} .{ }^{\circ} \mathrm{C}$ となる。発生炉の上部と下部との容 積伝熱倸数を同值と仮定することははななはだ大胆であ るが，前節に抢いて推論したごとく，伝熱に対する最 大抵抗は頁岩内部にあるという考え方にもとずいたわ けである。かようにして求めた予熱層の高さ $0.42 \mathrm{~m} は$ 実測による值とほぼ一致した。また， $h^{\prime}$ の值も前に計 算した乾溜筒の值と大差なく，伝熱に対する頁岩内部 の抵抗の大きいことをしめしている。

つぎに燃焼層をしらべてみる。発生炉にはいる頁岩 乾溜残渣をみるに，岸素の微粒子が緻密に分布されて いるが，肉眼によつて粒子の存在が認めうるからって の大きさは 10-3 $10^{-4} \mathrm{~cm}$, 程度と考元られる (Perry P. 1019)。すなわち分スの分子の大きさの $10^{4}$ 倍であ るから，孷素の消耗につれて，ガスの分子が乾溜残渣 の内部に拡散することは容易である, 180t炬の灰皿か ら出てくる頁岩の大粒を㓶つてみるに，炭素の消費さ れているのは表面から 3 4mm 程度のものである。

頁岩粒 (第10表) の表面から, 距離に対する容積打 よび面積炎計算すれば第13図のごとくなる。

\section{第13図 面岩の反忘完了容積と反応面積}

A. 頁岩粒全部に対するもの

B. $200 \mathrm{~mm}$ 以上の粒に対するもの

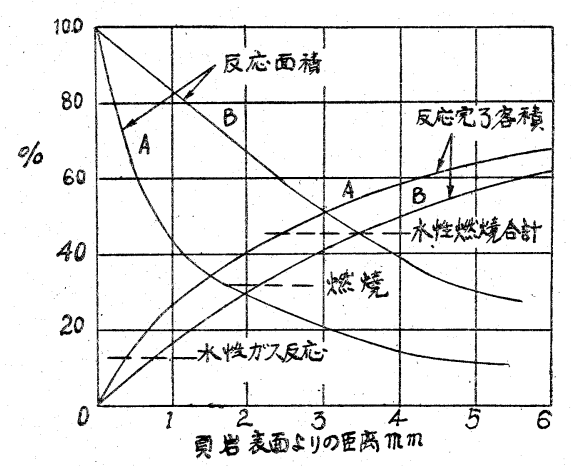

曲線 $\mathrm{A}$ は頁岩粒全部に対する值を示す。発生炉内に おいては頁岩の小粒は大粒の表面に附着し，あるいは 小粒が互に凝集していることも想定されるから，参考 のために $20 \mathrm{~mm}$ 以上の粒に対する值を求め曲線 $\mathrm{B}$ と した、多分実際の状態は両曲線の間にあるあのと考元 
られる。しかし区応面積に関しては，小粒の炭素分は 水性ガス反応によつて消耗しつくされる部分が多いか ら，燃焼に対してては曲線Bに近い值をとるべきである と考光られる。

第13図をみるに，燃焼のために酸素が拡散す心゙き距 離は, 表面から約 $0.5 \sim 3 \mathrm{~mm}$ 平均 $1.75 \mathrm{~mm}$ であり,こ れに対する平均反応面積は曲線 Bによれば約 70\% で ある。また式(9.)によって境膜俰数危計算し，境膜の 厚さを求めるに $1.3 \mathrm{~mm}$ となる。したがつて平均拡散 距離は合訢約 $3 \mathrm{~mm}$ である。ブラスト中の $\mathrm{N}_{2} \cdot \mathrm{H}_{2} \mathrm{O}$ を

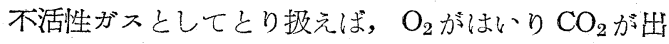
てくる等モル向流の拡散で沛る。Gilliland (Perry P.

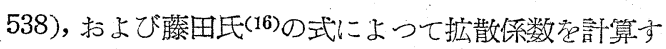
れば，それぞれ $0.167 \mathrm{~m}^{2} / \mathrm{hr}$ ，および $0.348 \mathrm{~m}^{2} / \mathrm{hr}$ をう る。

$$
\begin{aligned}
& \text { 拡散量の計算はつぎの式 }(10) \text { による。 } \\
& \quad N=D \frac{d e}{d x}=\frac{D}{R T} \cdot \frac{d p}{d x} \ldots \ldots \ldots \ldots \ldots . . .
\end{aligned}
$$

$N$ は拡散量 $\left[\mathrm{kg}-\mathrm{mol} / \mathrm{m}^{2} . \mathrm{hr}\right] ， D$.は拡散缧数 $\left[\mathrm{m}^{2} /\right.$ $\mathrm{hr}], \quad \boldsymbol{c}$ は濃度 $\left[\mathrm{kg}-\mathrm{mol} / \mathrm{m}^{3}\right], \quad x$ は拡散距離 $[\mathrm{m}]$, $p$ は分圧 $[\mathrm{atm}]$ である。酸素の分圧は燃焼閉始前 $0.0623 \mathrm{~atm}$, 平均 $0.0312 \mathrm{~atm}$, 拡散距離 $0.003 \mathrm{~m}$, 温度 $723^{\circ} \mathrm{K}$ として計算すれば，拡散量は $0.0293 \mathrm{~kg}-\mathrm{mol} / \mathrm{m}^{2}$ $\mathrm{hr}$ 西るいは $0.061 \mathrm{~kg}-\mathrm{mol} / \mathrm{m}^{2} . \mathrm{hr}$ となる。 $20 \mathrm{~mm}$ 以上 の頁岩粒の表面積は $135 \mathrm{~m}^{2} / \mathrm{m}^{3}$, 平均の反応面積はえ の70\%，酸素の供給量は $14.4 \mathrm{~kg}-\mathrm{mol} / \mathrm{hr}$, 発生炉の断 面積は $7.06 \mathrm{~m}^{2}$ であるから，燃燒層の高さは $0.72 \mathrm{~m}$ 西 るいは $0.35 \mathrm{~m}$ となる。実測によれば炉の中心におい ては後者の值の方が正しいと思われたが，外国におい ては一般に火層の位置が高かつたので，両者の平均を とることとした。すなわち，燃焼層高は $0.54 \mathrm{~m}$ ，予熱 層高はさきに計算したごとく $0.42 \mathrm{~m}$ ，合訂約 $1 \mathrm{~m}$ とな り，水性ガス反応層の高さは $2.5 \mathrm{~m}$ である。

\section{5 . 発生炉の能力}

発生炉内の方不組成については式(5.)がよく適合す ることを明かにしたが，まだ水性ガス反応の速度には 触れなかった。しかし発生灯の設計には重要な事項で あるから，その傾向をしらべて拉きたいと思う。 $50 t$, $100 \mathrm{t}$ および 180t 炉の発生炉の大きさはほほ同様であ り，頁岩も䇥分の精度は異るかも知れないが，大きさ は大差ないので，この三者の状態を比輘することとす る, 反応速度に関係のある数值は第 17 表のごとくであ る。

上表において然焼がス温度（理論）は第 3 図のそれ る用いた。還元層の容積は発生炉の容積から予蓺層拈

\begin{tabular}{|c|c|c|c|}
\hline の & 0t炻 & $100 \mathrm{t}$ 炻 & $80 t$ \\
\hline 岩装入量 $\mathrm{kg} / \mathrm{sec}$ & .579 & 1.16 & 2.31 \\
\hline ラスト溫度 & 82 & 86 & 87 \\
\hline 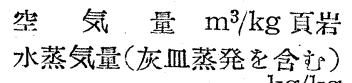 & 198 & 0.275 & 0.185 \\
\hline & .264 & 0.436 & 0.35 \\
\hline $\begin{array}{r}(\mathrm{kg}-\mathrm{mol} / \mathrm{sec}) \times 18 \\
\text { 生炉 ガス量 } \mathrm{m}^{3} / \mathrm{kg}\end{array}$ & $\begin{array}{l}1526 \\
0.278\end{array}$ & $\begin{array}{l}0.506 \\
0.347\end{array}$ & $\begin{array}{l}0.814 \\
0.231\end{array}$ \\
\hline $\begin{array}{c}\text { 蒸 気 } \\
\text { 口水蒸気量 }\end{array}$ & 2306 & 4075 & 0.334 \\
\hline & 333 & 173 & 0.772 \\
\hline$(\mathrm{kg}-\mathrm{mol} / \mathrm{sec}) \times 18$ & .0193 & 0.0331 & .0416 \\
\hline $\begin{array}{c}\text { 蒸気分解率 \% } \\
\text { 均ガス量(水蒸気会む) } \\
\mathrm{m}^{3} / \mathrm{kg}\end{array}$ & 12.64 & 6.53 & 5.1 \\
\hline 橈ガズ溫度 (理論) ${ }^{\circ} \mathrm{C}$ & 1,245 & 1,125 & 1,095 \\
\hline 生炉出口ガス溫度 ${ }^{\circ} \mathrm{C}$ & 719 & 700 & 636 \\
\hline 数本均ガ ス溫度 ${ }^{\circ} \mathrm{C}$ & 958 & 895 & 345 \\
\hline スの溫度降下 ${ }^{\circ} \mathrm{C}$ & 526 & 425 & 459 \\
\hline 元 層 容 積 $\mathrm{m}^{3}$ & 15.64 & 14.2 & 17.64 \\
\hline 又量 (平均溫度) $\mathrm{m}^{3} / \mathrm{sec}$ & 1.43 & 4.16 & 6.00 \\
\hline 時閶 & $5.4^{\prime}$ & .705 & $1.4 \%$ \\
\hline
\end{tabular}

\section{第17表 発生炉內の状態}

表中還元層とは水性ガス反応の層 よび然焼層として下部 $1 \mathrm{~m}$ の容積を除外したものとし た。 $50 t$ 炉および $100 t$ 炉の出口元ス温度は，第 4 表朽 よび第 5 表と式 (5)を用い，熱精算を作成して求めた ものである。空間率を 0.5 として通過時間を算出した。

反応は，微粒炭素の表面で起るものと考えられるか ら，ガスの温度，ことに理論然焼温度を使用するのは 不適当であるが，適当な資料がないのでこれを使用し， Arrhenius の式などによつて試算を行つてみたが，各 炉に対する民応量の計算值は差がはなはだ大きく実際 と一致しない。つぎに試算の一例矿あげる。

発生炉に抢ける水性がス反応の速度は， $1,000^{\circ} \mathrm{C}$ 附 近では，温度 $100^{\circ} \mathrm{C}$ 羑によつて 2 倍になるという報 告もあるが, Haslam 5の実験結果 (P. 118, Table 3) (6)を見るに，ガスの温度約 $300^{\circ} \mathrm{C}$ の上昇によつて，水 蒸気の分解による水素の生成率（\%）が 2 倍になつて いる。

温度 $x^{\circ} \mathrm{C}$ 降下によつて分解による水素の生成速度 (\%/sec)が か/2に低下するとすれば任意の温度に抢ける 生成速度はつぎの式 (11) によつて表わされる。

$$
\frac{d e}{d \theta}=\mathrm{C}_{0} \cdot \frac{1}{2}^{\frac{t_{0}-t}{x}}
$$

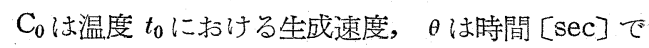
ある。よって $x=300^{\circ} \mathrm{C}$ とし, $50 \mathrm{t}$ 炉の理論ガス温度 


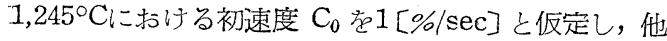
の炉のガス温度すなわち $1.125^{\circ} \mathrm{C}$ および $1,095^{\circ} \mathrm{C} に$ に ける初速度を計算すれば，省れぞれ 0.76 打よび 0.708 となる。つぎに式 (11) 在積分すれば式 (12) がえら れる。

$$
C_{\theta}=1.44 \frac{\mathrm{C}_{0} x \theta}{t_{0}-t}\left[1-\frac{1}{2}^{\frac{t_{0}-t}{x}}\right]
$$

$C_{\theta}$ は合計生成率 $[\%]$ である。第16表の值を用いて 各炉につき $O_{\theta}$ を計算すれば第18 表上段のごとくであ る。

\section{第18表 水蒸気の分解量の実際と計算}

炉 の種 類

実際の水蒸気分解率 \% 湿ガス中の $\mathrm{H}_{2} \%$ (式 5 によつて補正)

$O_{\theta}$ 計 算 值 (単位々\%に比例) 同比率 ((180 t 炬基準)

水蒸気送入量 $(\mathrm{kg}-\mathrm{mol} / \mathrm{sec}) \times 18$ 水蒸気实際分解量 $(\mathrm{kg}-\mathrm{mol} / \mathrm{sec}) \times 18$

同比率 式 (13) Kよる計算值 $k i$ 分解量計算值(水蒸気送入量 $7 k \theta$ )

同比輩

実際の水蒸気分解率之水素の生成率 [\%]と浽幾分 美異があるので式 (5) によつて補正し，湿がス中の $\mathrm{H}_{2}[\%] に$ に直した。これと $O_{\theta}$ (計算值) と堂比較する に50 t炬においては計算值が浃際值の約 3 倍となつて いる。すなわちガスの温度が变つても, 頁岩の発生炉 に抢いては，各炉の頁岩反応面温度の差は仮定よりも 小さいことを示めしている。よつてつぎに各炉の頁岩 反応面温度の差を考慮にいれないで反応量を求めてみ る。

式 (5) の水性がス反応は, $\mathrm{C}+\mathrm{H}_{2} \mathrm{O} \rightarrow \prec \mathrm{C}+2 \mathrm{H}_{2} \mathrm{O}$ $\rightarrow$ との組合せであるが，Haslam らによれば一次反応 と考光ることができる。頁岩の発生炬に抢いては未反 応の水蒸気拉よび不活性がスの量が多いから恒容恒圧 の反応と考元，っぎの反応速度式 (13) 丞使用する。

$$
\frac{-d n_{A}}{d \theta}=k n_{A}, \quad k \theta=2.3 \log \frac{n_{A 0}}{n_{A}} .
$$

$k$ は反応速度恒数 $\left[\mathrm{sec}^{-1}\right], \theta$ は時間 $[\mathrm{sec}], n$ oは 水蒸気の初めのモル数, $n_{A}$ は末反応水蒸気のモル数で ある.第16表の值它用いて $k \theta$ の值を求めれは第 17 表 下段のごとくである。水蒸気の分解量は小さいから，

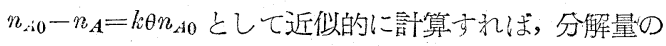
計算値の比率と実際値の比率とはよく一致方る。

式 (13) の中には温度の因子を含んでいない。ただ ガスの通過時間 $\theta$ 芷求めるために，ガスの理論的燃焼
温度と出口温度との対数平均を用いているが，もし各 炬に抢ける最高がス温度を $1,000^{\circ} \mathrm{C}$ と仮定して改算し ても，通過時間 $\theta$ の值はそれぞれ $6.0 ， 1.8$ および 1.5 sec となり第 17 表の值と大差がない。

頁岩の発生炬に抢いては内容の $94 \%$ 以上が灰分であ って, 酸素㤝頁岩内部に拡散して燃焼するから, 燃焼 によつて発生する熱量の幾部は頁岩に伝わつて蓄積さ れ，頁岩外部の燃焼がス温度は計算のようには上昗し ない。頁岩内に蓄積された蓺は下方から上昇してくるブ ラストの予熱に用いられるが，上部の水 180t炉 性がス反応層の加熱には直接的には役立 5.1 たない。燃焼がスから水性ガス反応層の 4.92 反応面に熱が伝わるには輻射や対流など 0.48 の抵抗があり，また吸熱反応による反応 4.92 面の温度低下も起る。このように考えれ 0.814 ば各炉に打ける反店層, ことに反応面の 0.0416 温度は実際に大差がないものと推定する 1 ことができる。ブラストの量を減少して 0.0536 も硫安の収率がほとんど変化しなかつた 0.0435 こともこの理由によるものと思われる。 i 上の計算に括いて各师の水性分ス反応 層の高さ考一定 $(2.5 \mathrm{~m})$ とした点にも検討の余地があ る。前節同椂に $50 \mathrm{t}$ 炉および $100 \mathrm{t}$ 炬について酸素の拡

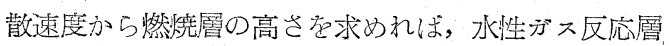
の高芑はとれ究れ $2.8 \mathrm{~m}$ および $2.2 \mathrm{~m}$ となる。この層 高の異る影響が何故上の計算結果に現れなかったかと いう原因としては,次のような点が帣元られると思う。 すなわちブラス下の空気量が多い归に扝いては，燃焼 分スの温度が上昇し水性方ス区応の速度は速いが，一 方に抢いて空気量の増加抢よでクリンカー発生によつ て燃焼層高が増し, 水性分ス反応層高が減じ, 反応時 間が短かくなる。またブラス下の水蒸気量を增加した 炬に胠いては, 水蒸気の濃度が高いから反応量は增加 するが，一方に晾いてがスの温度が低下し反応速度が 幄くなる。このような自動的調節作用があるために， 各炉に反広層高の影響が現われないのであろう。

式 (5) の関係と式 (13) の反応速度と觉用い試算 法を行うことによつて，近似的に発生炬の設計值をう ることができる。

\section{III 緒一言}

乾溜炉の熱精算，蓺伝導，水性沉ス区応速度などる 検討し設計基礎に関する考察を述べた。

本報告は撫順式乾溜炉の創設者長谷川清治氏，大橋 頼三氏の設計基礎, おょび多数の研究者技術者の永年 
の努力の成果基として生れたものであり、なお塞施 効果は挠順西製油工場日中接術者工員諸氏の協力の座 物である。また執筆にあたり多大の鞭捇と援助を頂い た東京工大森川清氏, 社長出光佐三氏に厚く謝意を表 する次第です。
交献

14）白来隆：化学機械拁会研究大会発表(昭28)

15) Kern: Process Heat Transfer, 657 (1950)

16）藤田重交：化学機械，15然，5号，234（昭26）

\title{
Analysis and Improvement of the Fushun Method of Oil Shale Carbonization (II)
}

\author{
by Kinji Kitawaki \\ (Idemitsu Kosan Co.,)
}

SYNOPSIS:-The foundamental data to design the $180 \mathrm{t}$ retort are required. The heat balance of the retort and the distribution of fixed carbon in shale, the function of the intermediate zone and brick arch between the distilling retort and producer, the capacity and heat transfer in the distilling chamber, the distribution of temperature and the height of combusion zone in the producer chamber etc were investigated.

1. The simplified equation derived from Haslam's experiments was explained by the actual operating data very well.

2. The amount of air blast should be reduced and the saturation temperature of the blast should be rised for the prevention of clinker formation and cracking of oil vapor distilled out.

3. Only one half of residual carbon in the distilled shale was gasified in the producer chamber and this carbon may be the effective source to replace the circlating hot gas from the regenerator.

4. The thermal conductivity of the shale decreascd very much as the drying and distillation proceeded.

5. Water gas reactions in the producer chamber were found to follow approximately to the first order reaction kinetically.

(380 ページょり続く) FA 16 (5) 177 9) Stewart, P. L. Gas, Los Angels 30 118, Mar. '54; FA 16 ( 5 ) 57; Kohl, J. et al, Pet. Engr '54 (3) D13; 影井, 分不協 7 (7) 35 '54; GWF' 93411 '52 10） AP, 朝日, 6.8 11）技術研究報。工ッセン：Vulkan Verlag, '54. $12 D M ; F A 16$ (3) 40 12) Dyson, A. et al, IP Prepr. Apr. 22 '53. 24; F' 14 (5) 162 '53; 同, Engr 198442 '54; F'A 17 (2) 134 '55; Zaslavskii, Yu. S et al * Nov '53, 1598; FA 16 (1) 185; 同, Jan. '54, 54; FA 16 (3) 159; SAEJ '55 (5) 32 13) Batten, C. et al (NCB, C'1 Res. Est.) Res. Rep. (163) 10pp. '53 ; FA 14 (6) 5 '53; Coll. Eng. 31 (1) 21 '54 14) 選鉱の進歩 (浮選), I. M. M. Lond'. '53, 465 98; FA 16 (2) 23 ’54 15) Orning, A. A. et al, J. Phys. C. 581044 '54; 本誌 34156 16) Bradacs, L. K. et al, Mikrochim. Acta (3) 229 '53; FA 15 (6) 146 '54 17) Schwarz, K. Mitt. Ver. Grosskessebesitz. (23) 405 '53; FA 14 (3) 109 18) Esso 研究所 (N. J.) Pet. Proc. '55 (1) 43; Fendler, H. et al VDI 96389 '54 19) Johnson, T, W. et al, Res. 7 (9) 356 '54 20) Eng 176 157; FA 14 (6) 114

21）工業に拉るラジオアイソトープ。(1953) 309 pp. \$8. N. Y.; FA 14 (3) 176 22) 日経, 5.28 23) 本誌 33116 